\title{
DMO - A dummy-made organ or a really working destination management organization
}

\author{
Andrea Holešinská / e-mail: holesinska@econ.muni.cz \\ Department of Regional Economics and Administration, \\ Faculty of Economics and Administration, Masaryk University
}

Holesinska, A. (2013). DMO - A dummy-made organ or a really working destination management organization. Czech Journal of Tourism, 2(1), 19-36. doi: 10.2478/cjot-2013-0002

\begin{abstract}
Destination management is considered as an advanced form of cooperation among tourism stakeholders who are associated in a destination management organization (DMO). In developed tourist destinations such as the Alpine regions, these institutions were formed spontaneously after a few years dealing with the socio-economic changes in demand to prove their competitiveness. This process strengthened their cooperation. In the Czech and Slovak Republic destination management does not have a long tradition. Although numerous tourism organizations have been established, their identification as DMOs is questionable especially considering the length of cooperation development in the Alpine regions. Therefore the article examines on an example of the Slovak Republic.
\end{abstract}

\section{Keywords}

DMO, Slovakia, destination management, cooperation, Czech Republic

JEL classification: L83 / Accepted: 30 August 2013 


\section{Introduction}

The Destination Management Organisation (DMO) is a network of tourism stakeholders. This network works on the basis of cooperation whose most advanced form is destination management.

It took fifty years before the cooperation in the Alpine destinations reached the stage of destination management (Bratl \& Schmidt, 1998). Due to the globalization the changes in demand forced the supply-side to react (for more see Pechlaner \& Tschurtschenthaler, 2003), a building phase. This led stakeholders from both public and business sector to more intensive cooperation (a growth phase), that in long-term reflected in the positive effects - synergies, e.g. elimination of externalities, economies of scale, or economies of scope. (Bieger \& Weibel, 1998). The effectiveness of cooperation increased (a concentration phase) when stakeholders focused on the needs of visitors, and adapted them into their offer (product). Thus, the competitiveness brought them to the cooperation. They interconnected their services and in so doing, they reduced their production costs. The course of events stimulated the activity of the private sector as the main generator of tourism. The role of the public sector moved to the issue of tourism policy such as creating the framework and conditions for tourism activities in regions. The cooperation was developing and apart from the optimization in division of tasks, the structure of destination was transformed thanks to the strong consolidation. DMO became a processoriented network structure of business type (Bieger, Laesser \& Beritelli, 2011).

Figure 1 The development of cooperation and its organization in the Alpine destinations

\begin{tabular}{|l|l|l|l|l|}
\hline \multirow{2}{*}{$\begin{array}{l}\text { Phase of } \\
\text { cooperation }\end{array}$} & Building & Growth & Concentration & Consolidation \\
\cline { 2 - 5 } & $\begin{array}{l}\text { Oos and } 60 \mathrm{~s} \\
\text { of the } 20^{\text {th }} \text { century }\end{array}$ & $\begin{array}{l}70 \mathrm{~s} \text { and } 80 \mathrm{~s} \\
\text { of the } 20^{\text {th }} \text { century }\end{array}$ & $\begin{array}{l}\text { 90s } \\
\text { of the } 20^{\text {th }} \text { century }\end{array}$ & $21^{\text {st }}$ century \\
\hline $\begin{array}{l}\text { Form of } \\
\text { cooperation }\end{array}$ & $\begin{array}{l}\text { Single-purpose } \\
\text { cooperation }\end{array}$ & $\begin{array}{l}\text { Strategic } \\
\text { partnership }\end{array}$ & $\begin{array}{l}\text { Destination } \\
\text { management }\end{array}$ & $\begin{array}{l}\text { Destination } \\
\text { management } 3^{\text {rd }} \\
\text { generation }\end{array}$ \\
\hline
\end{tabular}

Source: Bratl and Schmidt (1998); Bieger, Laesser, and Beritelli (2011); Holešinská (2012) - author's interpretation

In Slovakia as well as in the Czech Republic the organized cooperation in tourism developed in the 90 s of the 20th century when the Alpine regions have already applied destination management. At that time on the territory of the Czech and Slovak Republic various organizations were spontaneously established as a result of the development of tourism, especially in localities with tourist attractions, such as in the Czech Republic Czech Paradise - Association of Czech Paradise (1992) and in Slovakia the High Tatras - Association of Tourism High Tatras (1994) (Derco, 2012). The organizations, however, have difficulties to find partners, particularly in the private sector that is under the process of establishment (Baláž, 1995, 1998). Moreover, they face the problem of legitimacy 
(Bieger, 1996) - due to the lack of knowledge, their role is underestimated; they are not considered as authorities and suitable partners for cooperation. The situation has changed rapidly in the 21st century, when a large number of tourism organizations set up because of operational programs drawing from EU funds. (Holešinská, 2012, 2013) However, the organizations formed from the top do not stimulate cooperation. On the contrary, several side effects appear that reduce the competitiveness of destinations. Firstly, entrepreneurs are rarely involved in cooperation with the public sector, because they are not driven to minimize their costs, as it was in the case of the Alpine destinations (see Pechlaner \& Tschurtschenthaler, 2003). Secondly, these tourism organizations are expressively addicted to public funding and thus, they are limited in long-term strategic planning. (Holešinská, 2013) Furthermore, there is evidence that financing of these structures is unsystematic and their activities are not coordinated (Holešinská, Sauer \& Vystoupil, 2007). All this markedly reduces the effectiveness of cooperation. Despite this fact, there are tourism organizations whose intensity of cooperation is characteristic for destination management (a concentration phase).

In the Slovak Republic the situation is different. In 2010 the government approved Act No. 91/2010 Coll. on the promotion of tourism. The Act set the conditions for an organization of tourism and provided sources of its financing. Slovak tourism policy thus implemented a stimulating-growth measure to support the competitiveness of their destinations.

The paper aims to assess the current state of performance of the Slovak tourism organizations that were established according to the approved Act and then identify weaknesses and opportunities for further development of the Slovak tourism organizations (DMOs). The findings are compared with the results of the research conducted in the Czech Republic (Holešinská, 2010, 2012) and in the Alpine destinations (Bieger, 1996; Bieger, Laesser \& Beritelli, 2011; Bratl \& Schmidt, 1998; Pechlaner \& Tschurtschenthaler, 2003, etc.).

Research questions:

- How did the approved Act influence the financing of the Slovak tourism organizations (DMOs)? Are there noticeable differences between the Czech and Slovak way of financing DMOs?

- How did the legislatively set system of the organization of tourism influence the activity and cooperation of the Slovak DMOs? Are there disparities between the Czech and Slovak DMOs?

\section{Theoretical basis}

Destination management (DM) is presented as an intra-organizational phenomenon (Meriläinen \& Lemmetyinen, 2011). Therefore, the first studies were focused on the organizational structure and functions of destination management (Pearce, 1992; Bieger, 1996; Bratl \& Schmidt, 1998; Morrison, Bruen \& Anderson, 1998). Pearce (1992) applied the inter-organizational analysis to assort tourism organizations according to the extent 
of their functions (activities) into multi-function and mono-function. Bieger (1996) was more specific. He based the identification of DM's functions on the tourism product characteristics. Thus, he derived four functions (planning function, function of supply, interest representation function and marketing function) of destination management that matched with cooperative tasks (activities) performed by DMO.

Due to the process of globalisation and changes in tourism demand, destination management gains the great importance in terms of competitiveness (Pechlaner \& Tschurtschenthaler, 2003; Enright \& Newton, 2004). Ritchie and Crouch (2003) directly stated that "destination management is the key to maintaining a sustainable competitive advantage"(p. 183). Thus, the determinants of destination success are in the focal point of research (see Bornhorst, Ritchie \& Sheehan, 2010), precisely the performance of destination management (Beritelli, Bieger \& Laesser, 2007). Bratl and Schmidt (1998) have mentioned the relation between competitiveness and the performance of destination management in their study. At the same time they demonstrated the development of cooperation. The complexity of the development presents Figure 1 extended by the knowledge of Bieger, Laesser and Beritelli (2011).

Figure 2 Stages of tourism organization

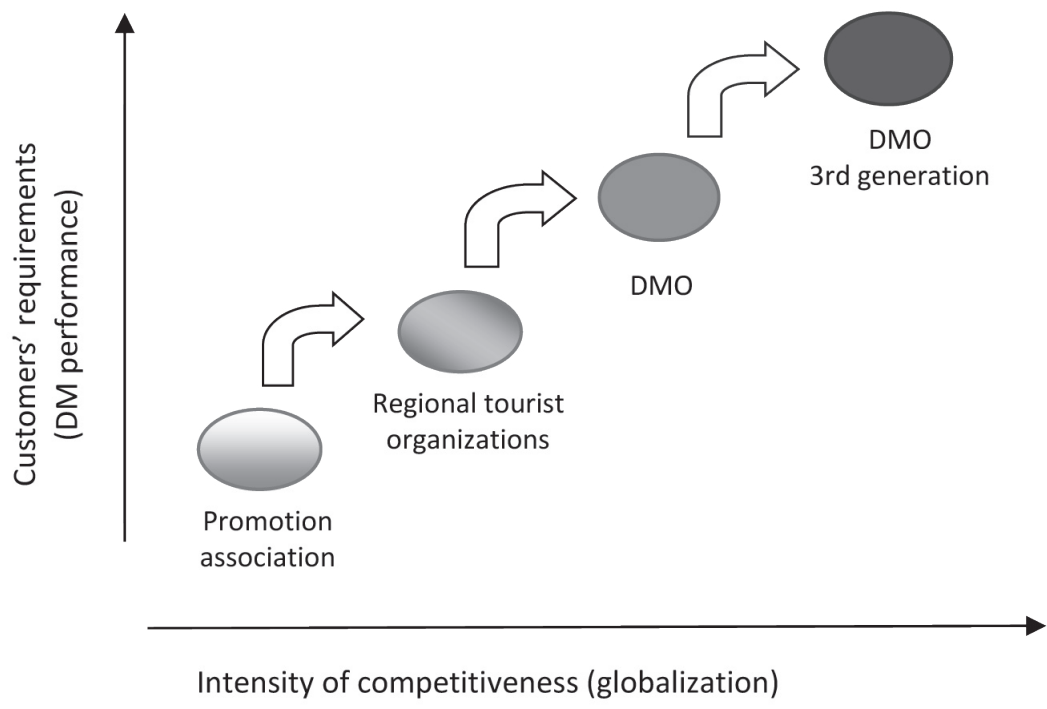

Source: Bratl and Schmidt (1998), and Bieger, Laesser and Beritelli (2011) - author's interpretaion

The issue of destination management's performance is broad. The predominant topic is cooperation/collaboration/partnership. A huge amount of research works has been written about relations and determinants that influence stakeholders' cooperation (Jamal \& Getz, 1995; Bieger \& Weibel, 1998; Bramwell \& Sharman, 1999; Watkins \& Bell, 2002; 
Sheehan \& Ritchie, 2005; Wang \& Xiang, 2007; or Beritelli, 2011). For example, Alter and Hage (1993) on the basis of the complexity of relationships defined three grades of cooperation:

- Limited cooperation based on an information exchange - see the building phase (Bratl \& Schmidt, 1998);

- Moderate cooperation based on cooperative marketing, purchase and lobby - see the growth phase (Bratl \& Schmidt, 1998);

- Broad cooperation based on an intensive cooperation in the field of tourism product and its distribution, and share in management - see the concentration phase (Bratl \& Schmidt, 1998).

Other researchers (Beritelli, Bieger \& Laesser, 2007) proved that among the factors affecting the complexity of cooperation were the experience and knowledge of tourism stakeholders and especially their mutual trust. Holešinská (2007) presented an overview of factors that have an impact on the performance of destination management and categorized them into external and internal.

\section{Methodology}

From the methodological point of view, the most often used methods in the research issue of destination management are inter-organizational theory (Pearce, 1992; Jamal \& Getz, 1995; Bramwell \& Sharman, 1999), network theories (Wang \& Xiang, 2007; Beritelli, 2011), corporate governance theories (Beritelli, Bieger \& Laesser, 2007), and importance-performance analysis (Enright \& Newton, 2004).

The research is based on all of these methods. On the basis of the inter-organizational analysis the functionality and structure of the financing of the Slovak DMOs was identified. The application of network analysis and the theory of corporate governance helped to examine the cooperation and the partnership network of the Slovak DMOs. Finally, the use of importance-performance analysis determined the factors that have an impact on the management of destination, precisely on the performance of the Slovak DMOs.

The overall situation in the Slovak Republic was assessed and weaknesses and opportunities of the researched issue were identified. To reach this, a comparison with the results of the research conducted in the Czech Republic (Holešinská, 2010, 2012) and in the Alpine destinations (Bieger, 1996; Bieger, Laesser \& Beritelli, 2011; Bratl \& Schmidt, 1998; Pechlaner \& Tschurtschenthaler, 2003, etc.) was applied.

As far as the methods of data collection are concerned, the qualitative research used structured interviews with responsible representatives of the Slovak DMOs and structured questionnaire that was modified from the research by Holešinská (2010). The research was conducted at the turn of 2012 and 2013. The total number of respondents was 23 Slovak tourism organizations registered in the database of the Ministry of Transport, Construction and Regional Development of the Slovak Republic. 


\section{Results}

\section{Financing}

The Slovak Act on the promotion of tourism in $\S 28$ enumerates the resources of funding for tourism organizations that can be divided into four categories (components): membership fees, grants (state subsidies, EU funds), income from commercial activities (sale of products and services; provisions; TIC revenues, selling advertising space), and donations (voluntary contributions from regional and local authorities, individuals and legal entities).

The research shows that the structure of the Slovak DMOs' budget is affected by the Act because the proportions of memberships fees and state subsidies is roughly at ratio of 50:50 (exceptions occur very rarely). Figure 3 illustrates an average of each components' shares of the Slovak and Czech DMOs' budget.

Figure 3 The structure of the Czech and Slovak DMOs budget financial resources (\%)

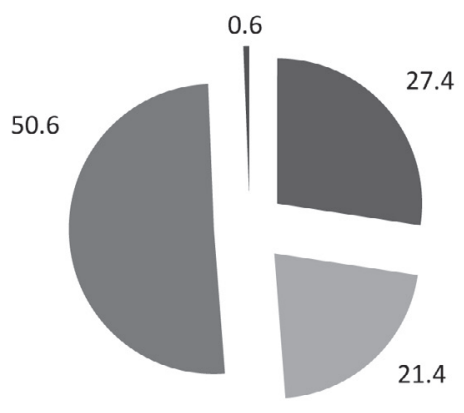

Czech Republic

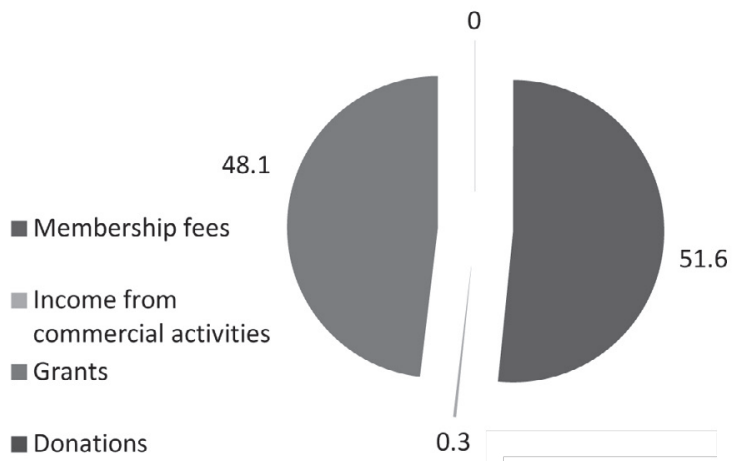

Slovak Republic

Source: Holešinská (2010) and author's research (2013)

While the Slovak DMOs show a balanced ratio of membership fees and grants $(\sigma=$ 15.3 for both resources), the Czech DMOs demonstrate a considerably great variability of each budget resources $(\sigma=31.3)$. The reason is that the legal form of the Czech DMOs determines the structure of their budget. For example, the legal form of a charitable trust has a higher percentage of income from the commercial activities than from the membership fees. On the contrary, the legal form of the association of corporate bodies relies on the membership fees. On average, the membership fees of the Czech DMOs reach around $30 \%$ of their budget (see Figure 3) which indicates a strong dependence on grants. On the contrary, it is typical of the Slovak DMOs that their income from the commercial activities is very rare - only one in six local tourism organizations carries out the commercial activities. The share of the income into the Slovak DMOs budget can be considered as marginal $(0.3 \%)$. In comparison with the Czech Republic, the income is 
a part of the Czech DMOs budget more often, which is again given by the differences in legal forms, as well as by the length of the Czech DMOs existence.

The interesting results reveal the structure of the membership fees that consist of the contributions from public bodies (mostly municipalities) and private entities. In the Czech Republic, municipalities are undoubtedly the biggest contributor in this category, i.e. the public sector dominates. This finding is valid also for the Slovak DMOs. However, thanks to the Act (the liability for business sector engagement in DMO) each Slovak DMOs has an appropriate share of the membership fees from entrepreneurs. On the contrary, in the Czech Republic only $47 \%$ of all local DMOs have the membership fees from the private sector. Again it is influenced by the chosen legal form of DMO.

An average amount of the Czech DMOs' budget at the local level is 3 million CZK (about EUR 120 thousand). The Slovak DMOs have on average EUR 150 thousand. Generally, DMOs budget must cover both operating (overhead) costs and core businesses costs. To be self-sufficient, the DMOs' financial resources, i.e. the membership fees and income from the commercial activities, must cover DMOs' costs. The Slovak Act positively supports the financial "self-sufficiency" of DMOs. According to the research the Slovak DMOs completely cover operating costs and partly core businesses costs as well. On the other hand, more pessimistic situation is in the Czech Republic where the DMOs financial resources fully cover only operating costs. It explains the high proportion of subsidies in the Czech DMOs budget.

Generally, the Slovak DMOs agree that the introduction of the Act enhanced the financing of tourism development, as well as obtaining subsidies. Nevertheless, each evaluation varies $(\sigma=0.8)$. The Slovak DMOs, however, mention the shortcomings of the Act that arise from its implementation in practice (for more details see the part Discussion).

\section{Activity and cooperation}

Financing has an impact on the activity (performance) of DMO. The structure of the performed activities refers to the range of DMO functions (Pearce, 1992). On the basis of the literature research (Pearce, 1992; Bieger, 1996; Bratl \& Schmidt, 1998), a set of fundamental destination management activities was compiled. The higher extent of activities the DMO performs in its core businesses, the more is multifunctional (Pearce, 1992) and the more reaches the concept of destination management (Bratl \& Schmidt, 1998). The following Figure 4 analyzes DMOs according to the number of activities done in the core business, either alone or in cooperation. The Czech DMOs contrary to Slovak ones reveal a higher degree of multi-functionality, and the extent of their performed activities shows the features of destination management. 
Figure 4 The extent of the Slovak and Czech DMOs functions

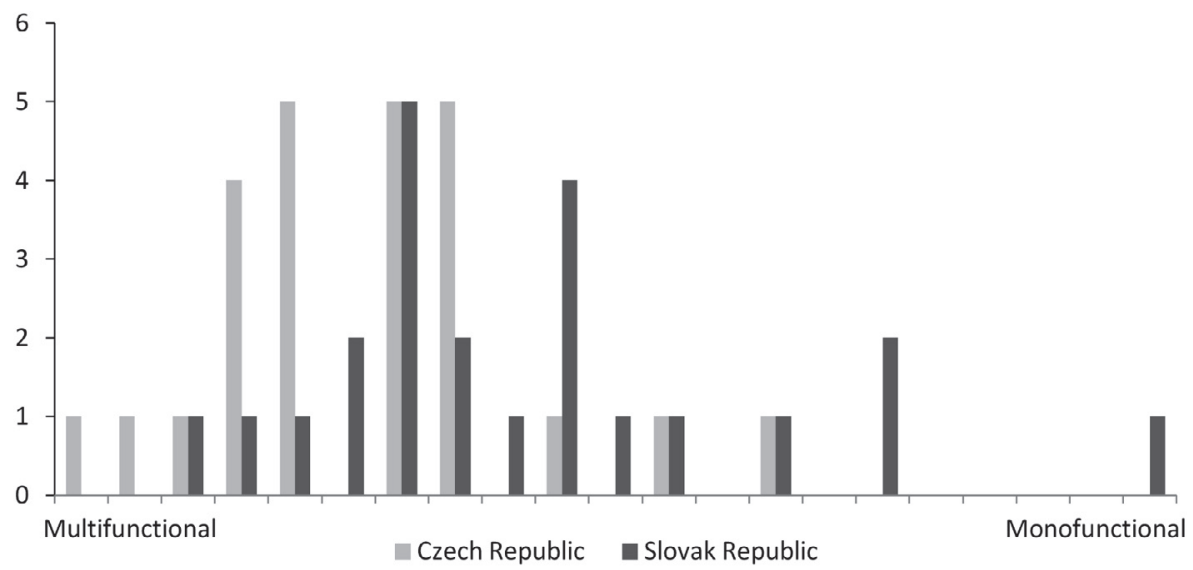

Source: Holešinská (2010) and author's research (2013)

The overview of the most performed activities in core business (Figure 5) indicates the functions of DMO in detail. From the Slovak DMOs perspectives, the frequency of recorded activities is much lower and shows a big variance in response $(\sigma=0.7$ to 2.1$)$. Whereas, the Czech DMOs reach minimum dispersion ( $\sigma=0.4$ to 1.4$)$. It is remarkable that the first four listed activities are performed by a majority of the Czech DMOs. This fact demonstrates the above mentioned finding that the Czech Republic has a higher maturity of the development of destination management than Slovakia.

From the perspective of DMO functions defined by Bieger (1996) the TOP list (Figure 5) suggests both the Czech and Slovak DMOs predominance of activities that belong to the representation interest function and marketing function. The planning function is covered as well, however, instead of destination development strategy, it is focused on the activity preparation and submission of grant applications (projects). This is something really specific (see "the Czech shortcut" in Holešinská, 2013) and differentiates the Czech development of cooperation and organization of tourism from the Alpine development.

In the TOP list (Figure 5) activities such as creating tourism products and their direct sales that belong to the function of supply are totally absent. For example, $60 \%$ of all Czech DMOs do not directly sell their tourism products and in the case of the Slovak DMOs it is $64 \%$. Despite these results, the Slovak DMOs indicated that the Act on the promotion of tourism made better conditions for the creation of tourism products and their direct sales.

However, it is necessary to examine the performed activities of the Slovak DMOs in terms of cooperation, see the functions of DMO and "cooperative tasks (activities)" (Bieger, 1996). The performed activities within cooperation thus determine the degree/ intensity of cooperation. The research results show that the Slovak DMOs have a higher intensity of cooperation than the Czech ones, because the Slovak DMOs performed 
more than $1 / 2$ of their activities on the basis of cooperation, whereas the Czech DMOs practise less than 1/3 activities in cooperation. The Slovak Act thus plays the main role in enshrining the cooperation among stakeholders and strengthening the principle of the public-private partnership.

Figure 5 The most performed activities in the core businesses of the Czech and Slovak DMOs

\section{Slovak Republic}

- Communication with stakeholders in destination

- Planning and realization of marketing activities

- Representation of destination interest on public

- Care of destination image

- Participation in trade fairs

- Public Relation

- Destination development strategy

\section{Czech Republic}

- Communication with stakeholders in destination

- Preparation and submission of grant applications (projects)

- Representation of destination interest on public

- Planning and realization of marketing activities

- Cooperation with tourist information centres

- Care of destination image

- Searching and motivation partners for cooperation

- Public Relation

- Destination development strategy

Source: Holešinská (2010) and author's research (2013)

According to the most frequently performed cooperative activities, i.e. interest representation, communication with stakeholders, participation in trade fairs and $\mathrm{PR}$, it is possible to identify the Slovak DMOs cooperation as moderate (see findings of Alter \& Hage, 1993).

Besides the intensity of cooperation, the quality of cooperation was investigated as well. Figure 6 summarizes overall findings. The evaluation includes both the public and private sector and moreover, it distinguishes the stakeholders who are members of the DMO and who are not (-others). The results prove the correlation in the evaluation of the National Tourism Authorities $(\mu=2.5)$ and other DMOs $(\mu=2)$. Regional authorities, municipalities (members and others) and entrepreneurs (members) have very similar marks. On the other hand, the evaluation of cooperation with other entrepreneurs is unequal. As foreign research findings point out it can be connected with the different maturity of trust among stakeholders (see Beritelli, Bieger \& Laesser, 2007). Figure 6 presents that the Slovak and Czech evaluation of cooperation with the Administration of National Parks (NP)/Protected Landscape Areas (PLA) and National Heritage Institute diverges. Whereas the Czech DMOs put better marks $(\mu=1.5$ each), the Slovak DMOs perceive the cooperation a grade lower $(\mu=2.5$ each). A possible argument is that in the Czech Republic there are DMOs in which the administration of NP/PLA is a co-founder of the DMO. 
Figure 6 The evaluation of cooperation with the selected partners (average)

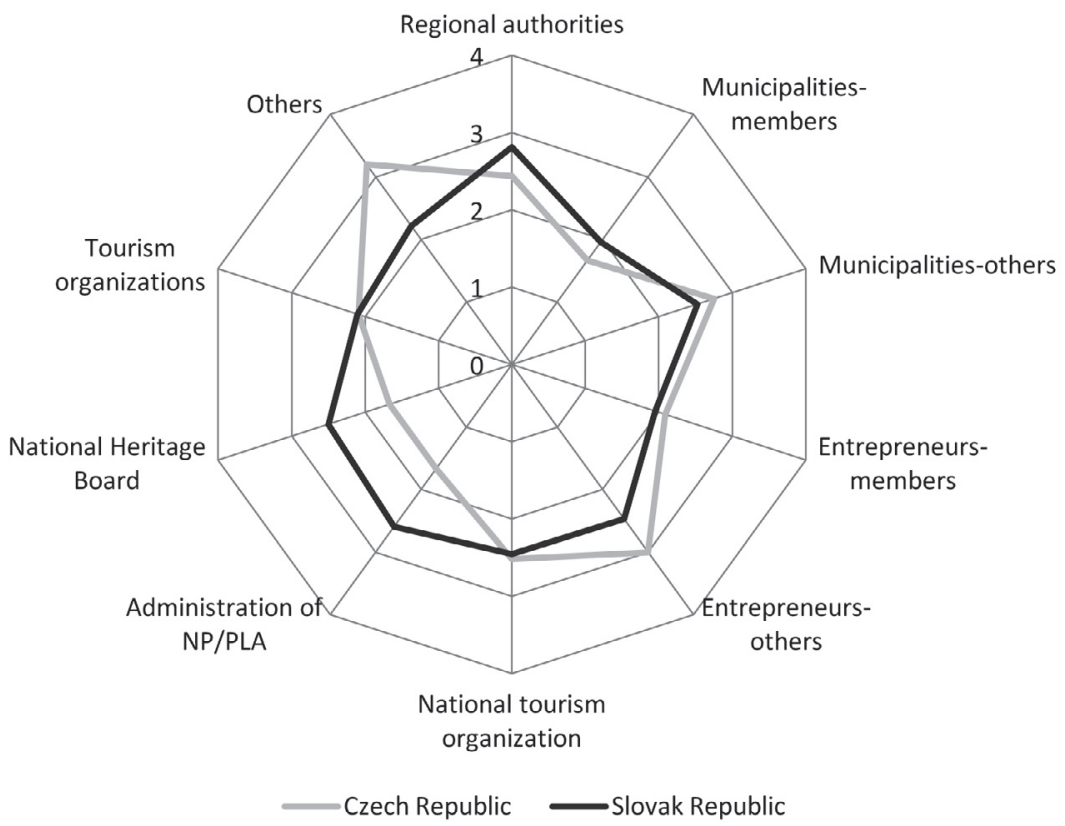

Rating Scale 1 = excellent cooperation, 2 = very good, 3 = good, 4 = sufficient, 5 = insufficient cooperation

Source: Holešinská (2010) and author's research (2013)

The cooperation is the cornerstone of destination management. However, the efficiency of destination management (the performance of DMO) is influenced by many factors (Bornhorst, Ritchie \& Sheehan, 2010; Beritelli, Bieger \& Laesser, 2007; Holešinská, 2007). With regard to this, DMOs were asked what kind of factors have a completely dominant influence (level 5) on their performance and which have a marginal impact (level 1). The results are recapitulated in graphs (Figure 7) that present variance (quartiles) and the average of each rated factor.

Generally, the Slovak DMOs demonstrate higher dispersion of ratings (heterogeneity) which can be linked to their short-term existence and already gained experience. The most noticeable discrepancy in the rating of both the Slovak and Czech DMOs is seen in the factors of their commercial activities and political decision.

The Slovak DMOs rate trust as a factor number one $(\mu=4.6)$ that have a completely dominant influence on their performance. The rating is in certain circumstances the result of the approved Act that set the partnership between the public and private entities. This reveals that the partnership of stakeholders is not based on mutual trust and the Slovak DMOs grapple with the problem. On the contrary, most of the Czech DMOs consider financial resources $(\mu=4.52)$ as an obstacle of their performance which dem- 
onstrates their stron addiction to the subsidies (grants) from operational programmes. Concerning the end of the programming period the Czech DMOs have to cope with the question how to replace the resource in their budget.

Apart from the above mentioned factors, the others, which according to the Slovak and Czech DMOs also have the most predominant impact on their effective performance, are:

- skills/knowledge/experience of DMO;

- cooperation between stakeholders;

- communication between stakeholders;

- skills/knowledge/experience of stakeholders with the DMO function;

- coordination between stakeholders.

Both the Slovak and Czech DMOs perceive that the mentality of stakeholders, autonomy of DMO and legislative framework dominantly affect their activity.

Figure 7 Factors influencing the performance of the Slovak and Czech DMOs

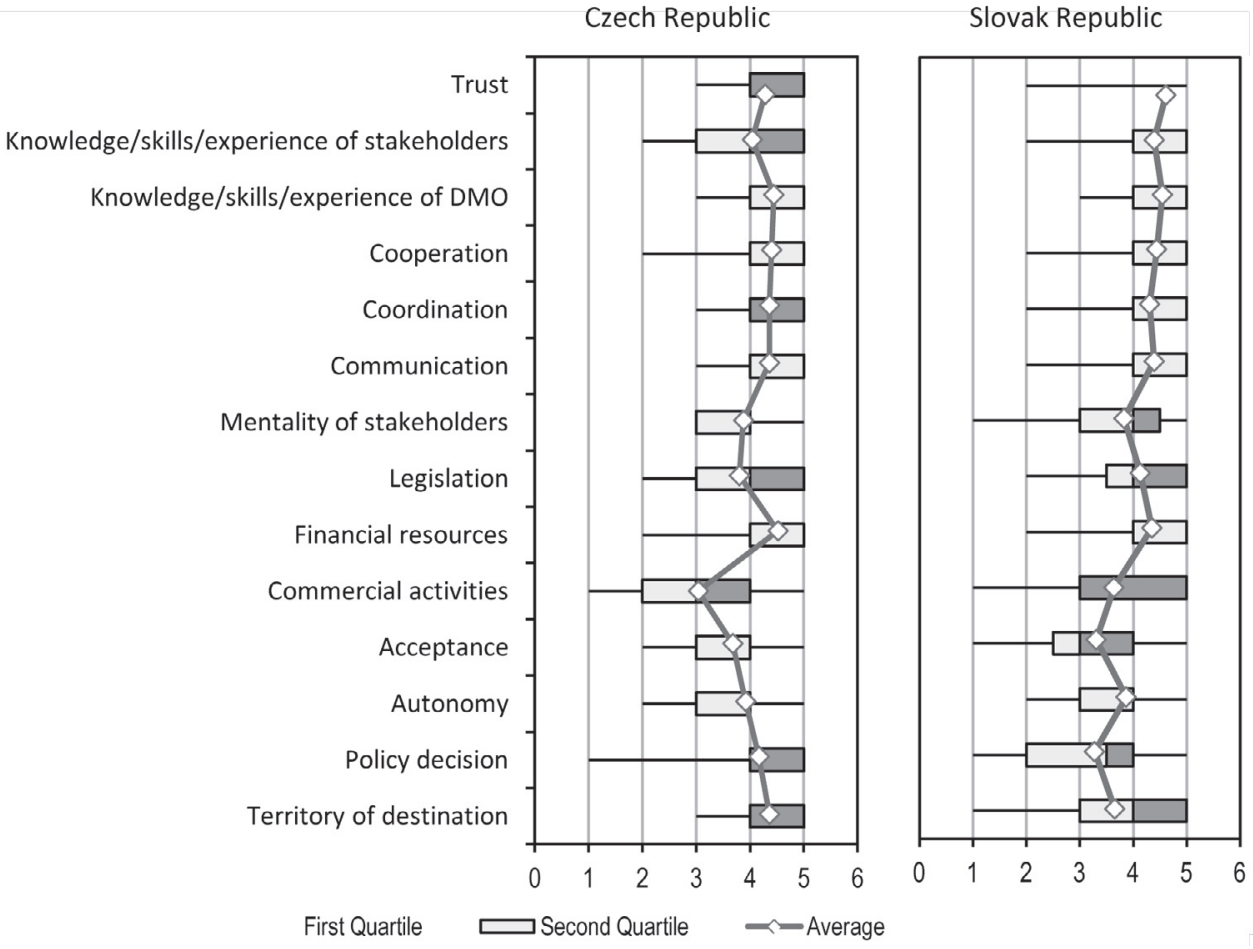

Rating scale 5 = completely dominant influence, $4=$ dominant influence, $3=$ moderate, $2=$ negligible, $1=$ no influence

Source: Holešinská (2010) and author’s research (2013) 
Although the factors such as the commercial activities and public acceptance of DMO are rated as moderate, the Slovak and Czech DMOs perceive each of them differently. While for some of the Slovak DMOs the commercial activities are completely dominant and the factor public acceptance is moderate the Czech DMOs distinguish them in the other way round.

Further findings are that the greatest diversity is visible at the factors such as the policy decision and territory of destination. The Czech DMOs rate both factors as (completely) dominant. The former indicates the instability of destination management's performance. As the Czech research revealed the public sector has the strong power in DMOs, precisely there is a financial reliance no membership fees from the public sector (Holešinská, 2012a). Considering the four-year electoral term at regional and local level each new government has different interests and thus makes diverse decisions. The later is related with the overlapping administrative boundaries, which limits DMOs in the drawing of their public financial resources. (Holešinská \& Jezdinská, 2013) On the contrary, the Slovak DMOs recognize both factors as moderate although the factor of territory of destination shows large variance $(\sigma=1.15)$ comparing to the Czech rating $(\sigma=0.7)$.

Generally the results of the research confirm that the Slovak tourism organizations are aware of the basic fundaments, see 3C-principle (Holešinská, 2010), of destination management.

\section{Discussion}

It was not the aim of the article to analyze the Slovak Act on the promotion of tourism, but to point out its implications, more precisely its impact on the development of management and organization of tourism in the Slovak Republic.

As far as the financing is concerned, there is evidence that the Act affects the structure of the Slovak DMOs budget. The ratio of the membership fees to grants (state subsidies) is the same. The source income from the commercial activities has a minimal share, which is obvious considering the short existence of the recently established DMOs. The Act, however, supports the use of the resource (see $\$ 28$ ). Thanks to the Act, budgets of all Slovak DMOs have the membership fees from entrepreneurs, and thus the excessive dependence on public financial resources is eliminated (see the problem of the Czech DMOs).

With regard to the membership fees, it is necessary to mention two facts - one is positive and one is negative. The former is that the Act indirectly leads municipalities to derive their membership fees from collected accommodation taxes. In comparison with the Czech system the membership fees of municipalities are counted per capita. This way forces the Slovak local tourism organizations (DMOs) to perform such activities that would stimulate entrepreneurs to an action. Thus, the Act strengthens the multiplier effect of tourism because the income from tourism is reinvested into the tourism organization (DMO). The later is that the Act itself hobbles the possibility of multiplica- 
tion because it guarantees each member only one vote $(\S 17$, section 8$)$ regardless the amount of their deposit (membership fee). Whereas the joint-stock company divides the voting rights according to the deposit, the legal form of the Slovak tourism organizations (DMOs) is a kind of hybrid. Thus, members of the Slovak DMOs perceive it as injustice and to some extent they are demotivated in partnership (cooperation). In case that the situation remains untouched, there is a probability that these inconvenient conditions of cooperation will reflect in crimping the destination growth. This is an issue that requires further analysis and certainly should not be left unnoticed.

The legal provision of the state subsidies - another financial resource of the Slovak tourism organizations (DMOs) - has also weaknesses. According to the Act, each registered local tourism organization can apply for the subsidy amounting to the collected membership fees from the previous year, but maximum is $90 \%$ of the accommodation tax collected from all member municipalities (paraphrase of $\S 29$ section 4). Although the Act's formulation strengthens the multiplier effect of tourism, it does not provide the local tourism organizations with the stabile system of subsidies. Firstly, it does not ensure that the subsidy will always be a maximum (authors' note: It is a question of the Act's interpretation). And secondly, the reliance of subsidy on the collected accommodation taxes from the previous calendar year can cause that in the case of natural disasters (floods or gust of wind) a local tourism organization gets "nothing". The Austrian laws solve the problem by five-year average (median) (Holešinská, 2012a).

According to the Act, the state subsidies are fixed on a calendar, precisely a fiscal year (§ 29 section 2), which is not systematic because it reduces the effectiveness of long-term planning of the destination development. This situation is most evident in the destinations with winter recreation when the winter season extends beyond one year.

The major weakness of the Act that can easily lead to the ineffective development of tourism destinations and waste of public financing is the definition of the purpose of the subsidy. The Act states that the subsidy is intended for "the implementation of such activities that are associated with the core businesses of the tourism organization" (§ 29 section 1). As practice reveals it is a very vague definition. The Slovak DMOs commented that the Act encourages more developed destinations that have already built the infrastructure in comparison with the destinations with low importance of tourism for which the construction of the necessary infrastructure is expensive. Questions arise: Should the construction of tourism infrastructure be really invested from the public sources? Does DMO possess any infrastructure? Who is the primary provider of tourism services? The Czech Republic is the example where a plenty of tourism infrastructure was built from public financial resources, regardless the effective demand (Vystoupil \& Šauer, 2010). Another example of a vaguely defined purpose of subsidies offers a comment that there is a disparity in financing between the destinations with great importance of tourism (characterized by long-term stays) and one-day-trip destinations (with short-term stays). The "disadvantage" is that a one-day-trip destination has low bed capacity, which means low overnights - fewer collected accommodation taxes and thus, less possibility to raise a high state subsidy. This situation is a matter of a broad discussion. A possible answer is hidden in the principles of the multiplier effect and particularly the stabiliza- 
tion function of tourism. The core of the later is that tourism can stimulate the economic growth in a destination but certain conditions must be met, otherwise the public financial resources are spent inefficiently. To avoid the inefficiency the Swiss laws clearly define activities that are granted (Holešinská, 2012a). There are supported soft projects covering not only competitiveness but also sustainability.

Moreover, this research has shown that due to the short existence of the Slovak DMOs, these organizations perform a low extent of activities than it is common for destination management (Bratl \& Schmidt, 1998). The same evidence can be seen in the functions of DMO (see Bieger, 1996). As far as the development of management and organization of tourism in the Slovak Republic is concerned, there is a positive finding that the performed activities are mainly carried out in cooperation in comparison with the case of the Czech Republic. This can be the result of the approved Act, as well as the fact that most of the Slovak DMOs were established by stakeholders who had been cooperated with each other before the Act was valid. The cooperation between stakeholders within the DMO can be classified as moderate (Alter \& Hage, 1993). On average, the Slovak DMOs evaluate the cooperation with their partners (very) well. The best cooperation is with the municipalities that are members of the DMO and the "worst" is the cooperation with regional authorities. The analysis of the factors that affect the management (performance) of the Slovak DMOs implies the conformity with the fundamental principles of destination management.

Are the Slovak tourism organizations the real DMOs or they are dummy-made organs? The Slovak tourism organizations themselves comment that a number of dummy-made organs were established without any tourism potential. One of the examples are spatially large destinations of the local tourism organizations Záhorie (4), Turistický Novohrad and Podpolanie (19) and Horný Zemplín and Horný Šariš (32) that are classified in category IV with the regional importance of tourism (Tourism Regionalization in the Slovak Republic , 2005), and therefore have low overnights. On the contrary, the second example is spatially small local tourism organizations located in frequently visited areas (see the High Tatras) that illogically fragment the natural tourist destination. The problem with the disproportional space division had to be obvious before the Act approval. The truth is that the problem is hardly detected by any law. Unfortunately, the time will solve the situation. In this case it is impossible to apply the foreign experience from the Alpine destinations because the development was spontaneous based on the market mechanism (see Pechlaner \& Tschurtschenthaler, 2003).

\section{Conclusion}

To a certain extent, the Slovak tourism organizations can be considered as dummy-made organs because they have not been formed naturally, but as the result of the legislation process. The consequences associated with this process are the penalty of speeding up the destination management that has lasted in the Alpine regions already for fifty years (Bratl \& Schmidt, 1998). The spatial distribution (Figure 8) of the registered tourism organizations, however, reveals that more than a half of all organizations covers the area 
with international importance of tourism (category I) and more than $1 / 4$ has the status of national importance (II categorization), compare the map the Tourism regions categorization in medium-term (Regionalization of tourism in the Slovak Republic, 2005).

Although the article offers an assessment of the development of destination management in Slovakia only for the first year of full operation, certain conclusions can be made. The Slovak Act is certainly set to ensure the cooperation on the principle of public-private-partnership and to reinvest (at least partially) the revenue generated by tourism back to destinations.

The weaknesses of the law have already been discussed above and they are, for example, a vague definition of the purpose of the state subsidy; restrictions on voting rights (limiting the proportion of the membership fees); instability of grant funds, and to a certain extent, disruption of the natural development of the cooperation among stakeholders.

Besides the opportunities how to improve the act and the development of destination management mentioned in the section Discussion, there is an opportunity for conducting (regular) research and investigations, whose findings would serve as a source for further improvement of the current version of the Act. The responsibility for this task should be carried by the competent ministry.

\section{Literature}

Act No. 91/2010 Coll. on the promotion of tourism, as amended. Slovak Republic.

Baláž, V. (1995). Five years of economic transition in Slovak tourism: successes and shortcomings. Tourism Management, 16(2), 143-159.

Baláž, V., \& Mitsutake, M. (1998). Japanese tourists in transition countries of Central Europe: present behaviour and future trends. Tourism Management, 19(5), 433-443.

Beritelli, P. (2011). Cooperation among prominent actors in a tourism destination. Annals of Tourism Research, 38(2), 607-629.

Beritelli, P., Bieger, T., \& Laesser, C. (2007). Destination Governance: Using Corporate Governance Theories as a Foundation for Effective Destination Management. Journal of Travel Research, 46(August), 96-107.

Bieger, T. (1996). Management von Destinationen und Tourismusorganisationen. München: Oldenburg Verlag.

Bieger, T., \& Weibel, C. (1998). Möglichkeiten und Grenzen des kooperativen Tourismusmarketing- Schaffung von Tourismussystemen als Strategien gegen Destinationsähnliche Konkurrenzprodukte. In Destination Marketing - Reports of the AIEST Congress 1998 (pp. 167-200). St. Gallen: AIEST.

Bieger, T., Laesser, C., \& Beritelli, P. (2011). Destinationsstrukturen der 3. Generation - Der Anschluss zum Markt. St. Gallen: Universität St. Gallen. Retrieved from https://www.alexandria.unisg.ch/ export/DL/206538.pdf

Bornhorst, T., Ritchie, J. R. B., \& Sheehan, L. (2010). Determinants of tourism success for DMOs and destinations: An empirical examination of stakeholder's perspectives. Tourism Management, 31(5), 572-589. 

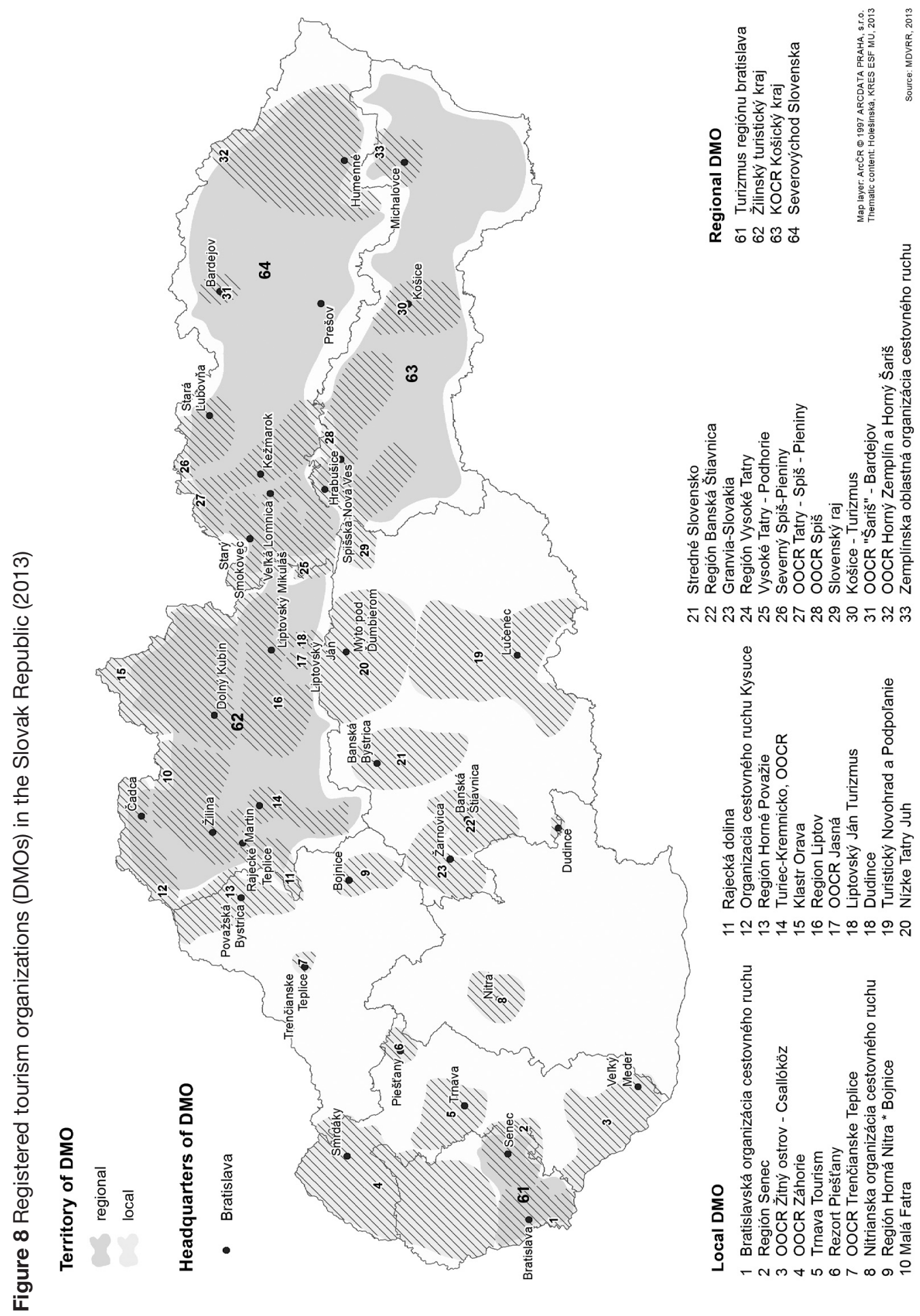
Bramwell, B., \& Sharman, A. (1999). Collaboration in local tourism policymaking. Annals of Tourism Research, 26(2), 392-415.

Bratl, H., \& Schmidt, F. (1998). Destination Management. Wien: Wirtschaftsministerium, ÖAR-Regionalberatung, GmbH.

Derco, J. (2012). Destination Governance in the Czech Republic, Slovakia and Poland. Tourism Planning E Development, December, 11 p. doi: 10.1080/21568316.2012.747987

Enright, M. J., \& Newton, J. (2004). Tourism destination competitiveness: a quantitative approach. Tourism Management, 25(6), 777-788.

Fyall, A., \& Garrod, B. (2005). Tourism marketing: a collaborative approach. Clevedon: Channel View Publications.

Holešinská, A., Šauer, M., \& Vystoupil, J. (2007). STUDIE - Náurh destinačního řízení turistické oblasti Pálava a Lednicko-valitcký areál. Př́padová studie - Mikulovsko (Study - The proposal of destination management of Pálava and Lednicko-valtický area - case study Mikulov region). Brno: Masaryk University.

Holešinská, A. (2007). Destinačni management aneb Jak ř́́dit turistickou destinaci (Destination management and How to manage a tourist destination). Brno: Masaryk University.

Holešinská, A. (2010). Destination management jako nástroj regionálni politiky cestouního ruchu (Destination management as an instrument of regional tourism policy) (Doctoral dissertation). Brno: Masaryk University.

Holešinská, A. (2012a). Destination management jako nástroj regionální politiky cestovního ruchu (Destination management as an instrument of regional tourism policy). Brno: Masaryk University.

Holešinská, A. (2012b). Organizace a řizeni cestovního ruchu v České republice - kde je zakopán pes (Organization and management of tourism in the Czech Republic - where is the rub). In A. Holešinská (Ed.), 3. Mezinárodni kolokvium o cestovním ruchu. Sbornik přispěvků. Pavlov, 6.-7. zář́ 2012 (pp. 27-36). Brno: Masaryk University.

Holešinská, A. (2013). Zkušenosti s řízením cestovního ruchu a jeho legislativní úpravou v zahraničí (Experience in managing tourism and its legal regulations in abroad). Czech Hospitality and Tourism Papers, (in press).

Holešinská, A., \& Jezdinská, P. (2013). Administrativní hranice jako překážka pro destinační management (Administrative boundaries as a barrier to destination management). In V. Klímová \& V. Žítek (Eds.), XVI. mezinárodni kolokvium o regionálních vědách. Sbornik príspě̀ki̊. Valtice 19.-21. června 2013 (pp. 610-616). Brno: Masaryk University.

Jamal, T. B., \& Getz, D. (1995). Collaboration theory and community tourism planning. Annals of Tourism Research, 22(1), 186-204.

Meriläinen, K., \& Lemmetyinen, A. (2011). Destination network management: a conceptual analysis. Tourism Review, 66(3), 25-31.

Ministry of Economy of the Slovak Republic. (2005). Regionalizácia cestovného ruchu v Slovenskej republike (Regionalzation of tourism in the Slovak Republic). Bratislava: Author. Retrieved from http://www.telecom.gov.sk/index/index.php?ids=102432

Morrison, A. M., Bruen, S. M., \& Anderson, D. J. (1998). Convention and Visitor Bureaus in the USA: A profile of bureaus, bureau executives, and budgets. Journal of Travel and Tourism Marketing, 7(1), 1-17.

Pearce, D. G. (1992). Tourist Organizations. Harlow: Longman Group UK Ltd.

Pechlaner, H., \& Tschurtschenthaler, P. (2003). Tourism Policy, Tourism Organisations and Change Management in Alpine Regions and Destinations: A European Perspective. Current Issues in Tourism, 6(6), 508-539. 
Ritchie, J. B, \& Crouch, G. I. (2003). The competitive destination: a sustainable tourism perspective. Wallingford: CABI publishing.

Sainaghi, R. (2006). From contents to processes: Versus a dynamic destination management model (DDMM). Tourism Management, 27(5), 1053-1063.

Sheehan, L. R., \& Ritchie, J. R. B. (2005). Destination stakeholders: Exploring Identity and Salience. Annals of Tourism Research, 32(3), 711-734.

Vystoupil, J., \& Šauer, M. (2010). Regionální operační programy jako nástroj popdory cestovního ruchu v ČR (Regional operational programs as an instrument of tourism support in the Czech Republic). Regionální studia, 4(1), 38-50.

Wang, Y., \& Xiang, Z. (2007). Toward a Theoretical Framework of Collaborative Destination marketing. Journal of Travel Research, 46(August), 75-85.

Watkins, M., \& Bell, B. (2002). The experience of forming business relationships in tourism. International Journal of Tourism Research, 4(1), 15-28. 